\title{
DO DIFFERENT DISCUSSION ACTIVITIES IN DEVELOPING SCIENTIFIC ARGUMENTATION AFFECT STUDENTS' MOTIVATION IN CHEMISTRY?
}

\author{
Sri Rahayu*, Klaudia E. N. Bambut, Fauziatul Fajaroh \\ Universitas Negeri Malang, Indonesia \\ *e-mail: sri.rahayu.fmipa@um.ac.id
}

\begin{abstract}
Argumentation has an influence on students' cognitive skills as well as learning motivation through the increase in confidence, science, and social activities. Argumentation skills can be trained through different patterns of discussion - cooperative and collaborative. This study aimed to reveal the learning motivation of students who enacted their argumentation skills using Argument-Driven Inquiry (ADI) with cooperative and collaborative discussions. The research design was a case study that engaged 95 Grade 11 students who were learning the chemical equilibrium topic. The research instrument employed was the ARCS motivation questionnaire that consisted of four aspects, namely attention, confidence, relevance, and satisfaction. The quantitative data were collected from the ARCS questionnaire and the qualitative data were collected from classroom observation, interview, and students' discussion process. The data were analyzed using designed criteria and percentages, and were described qualitatively. The study found that students who learn chemistry through cooperative-ADI gain a high average motivation. For each aspect of motivation, the majority of students in the cooperative-ADI discussion show a higher level of motivation compared to students' level in the collaborative-ADI discussion. The study has implications on how to design a discussion group in terms of motivation.
\end{abstract}

Keywords: argumentation, Argument-Driven Inquiry, cooperative discussion, collaborative discussion, learning motivation

\section{APAKAH KEGIATAN DISKUSI YANG BERBEDA MEMPENGARUHI MOTIVASI SISWA DALAM KIMIA?}

\begin{abstract}
Abstrak: Argumentasi memiliki pengaruh terhadap keterampilan kognitif siswa serta motivasi belajar melalui peningkatan rasa percaya diri, minat pada sains, dan aktivitas sosial. Keterampilan berargumentasi dapat dilatih melalui pola diskusi yang berbeda, kooperatif dan kolaboratif. Penelitian ini bertujuan untuk mengetahui motivasi belajar siswa yang berlatih argumentasi dengan menerapkan pembelajaran Argument-Driven Inquiry (ADI) melalui diskusi kooperatif dan kolaboratif. Desain penelitian adalah studi kasus yang melibatkan 95 siswa kelas 11 yang sedang mempelajari topik kesetimbangan kimia. Instrumen penelitian yang digunakan adalah angket motivasi ARCS yang terdiri dari empat aspek yaitu perhatian, keyakinan, relevansi, dan kepuasan. Data kuantitatif dikumpulkan dari kuesioner ARCS dan data kualitatif dikumpulkan dari observasi kelas, wawancara, dan proses diskusi siswa. Data dianalisis menggunakan kriteria dan persentase yang dirancang dan dideskripsikan secara kualitatif. Hasil penelitian menemukan bahwa siswa yang belajar kimia melalui kooperatif - ADI memperoleh motivasi rata-rata yang tinggi. Untuk setiap aspek motivasi, mayoritas siswa di kooperatif-ADI menunjukkan tingkat motivasi yang lebih tinggi dibandingkan dengan siswa pada kolaboratif-ADI. Penelitian ini berimplikasi pada bagaimana merancang kelompok diskusi dari segi motivasi.
\end{abstract}

Kata Kunci: argumentasi, Argument-Driven Inquiry, diskusi kooperatif, diskusi kolaboratif, motivasi belajar

\section{INTRODUCTION}

Recent research findings show that the success of students' scientific learning process is affected by their learning motivation (Boekaerts \& Cascallar, 2006; Kaplan \& Flum, 2009; Velayutham \& Aldridge, 2011). Unfortunately, many studies revealed that student's attitudes, interests, and motivation towards science learning decline throughout their years at school, especially during secondary school years (Osborne, Simon, \& Collins, 2003). Research conducted by Hampden-Thompson \& Bennett 
(2013) presents the lack of students' interest in scientific activities, such as chemistry lab work, which is caused by their inability to relate the practices with the background of scientific concept. As for the fact, that interest plays an essential role that affect students' intrinsic motivation (Simpkins, David-Kean, \& Eccles, 2005). Improvement of learning motivation highly relies on the students' approach to get involved in the learning process.

According to social constructivism, students will learn school science topic by constructing knowledge with peers in terms of social activity, such as through discussion, argumentation, or debate. Enthusiasm to learn science can be enhanced through activities that enforce students to discuss controversial issues occurring in society by investigating evidence, reviewing relevant theory or scientific concepts, and identifying ideas or suggestions for problem-solving in the form of argumentation (Jocz, Zhai, \& Tan, 2014). Continuously trained argumentation skills could generate a scientific experience that improves students' competence, as well as their interest in science (Bathgate, Crowell, Schunn, Cannady, \& Dorph, 2015). Thus, argumentation is acknowledged affecting various factors that accelerate motivation, such as interest, confidence, or learning motivation in science learning. However, to the best of our knowledge, there has been no specific research on the effect of a learning process using argumentation on learning motivation, primarily in learning chemistry.

Argumentation is a skill that enables students to decide their stand on a problem and promote it to other people. During the argumentation, students may encounter debate due to the different perceptions (Osborne \& Patterson, 2011). Consequently, they are prompted to defend their argument by delivering refutation and counter-question (Berland \& Reiser, 2008; Chen, Wang, Lu, Lin, \& Hong, 2016). However, the active debate is also greatly influenced by internal student factors, such as whether the student is an introvert or an extrovert. An extrovert will certainly like arguing with each other, but an introvert tends to be shy and uncomfortable during an argument (Condon \& Ruth-Sahd, 2013). An introverted student tends to limit himself to engage in social activities because he does not enjoy and find no use in these activities (Ericson \& Gardner, 1992).

One of the instructional models that actively associate students to argue is ArgumentDriven Inquiry (ADI) model. This model was developed by Sampson \& Gleim (2009) as a solution to advance students' inquiry skills in learning science by engaging students to write an argument. ADI consists of eight learning steps, including: (1) task identification; (2) data collection; (3) tentative argument production; (4) interactive argument session; (5) reflective discussion; (6) investigation report; (7) report peer-review; and (8) report revision (Sampson \& Gleim, 2009). ADI model is known to improve scientific argumentation skills and the quality of the resulting arguments (Putri, Rahayu, \& Fajaroh, 2019). This model was developed by including collaborative group discussions. The collaborative discussion was chosen since it encourages students to perform social activities, such as sharing information, ideas, and refutations aiming to develop a better understanding; thus, it creates an active argumentation process ( $\mathrm{Lu}$, Chiu \& Law, 2011). Collaboration enhances students'self-efficacy level and their involvement in the learning process, while self-efficacy is an intrinsic factor that boosts students' motivation (Scager, Boonstra, Peeters, Vulperhorst, \& Wiegant, 2016). Research conducted by Waite \& Davis (2006) also reveals that collaboration influences intrinsic motivation acceleration in the form of the interest toward the materials, as well as outward motivation improvement in the form of better learning results. Other than that, a combination of inquiry and collaboration also promotes deeper interactions theoretically between students and materials. Thus, it improves students' conceptual understanding that accelerates students' learning motivation (Blumenfeld, Rogat, \& Krajcik, 2006).

However, previous research found that collaborative discussion patterns had weaknesses, such as not all of the group members master the materials they learned even when the group results showed a high level of conceptual mastery. Therefore, not all of the group member is actively involved in the discussion (Sampson \& Clark, 2009). Besides, different cognitive levels also provoked domination in the group, so the group results tend to reflect one student's idea (Chinn \& Clark, 2013). Lack of teacher monitor during discussion activities also greatly 
affects the failure of collaborative discussions in improving argumentation skills, especially for introvert students. Extroverted students will certainly dominate discussion activities and cause other students to be afraid to argue for fear of being blamed for their opinions (Beatty, McCroskey, \& Heisel, 1998). Therefore, when training students to argue through group activities, teachers must consider the stages or patterns of discussion, such as what can capture both the cognitive and social aspects in the argumentation so that the skills are not only acquired in groups but can also be adapted by each member of the group (Le, Jannsen, \& Wubbles, 2016).

Many science classrooms implement cooperative discussion due to its ability to enhance students' social interaction aiming to share learning purposes (Day \& Bryce, 2012). In contrast to the collaborative discussion, the cooperative discussion has five primary features, namely: (1) positive interdependence, where students' need each other to achieve the common learning goal, (2) direct interaction between students, where there are face-to-face interactions among students imbued by positive interdependence, (3) individual responsibilities, where each of group member has to master the materials or underlying concept of the discussed issues so that they can give applicable ideas or reasoning, (4) interaction skill among individu in the group, where the students in the group know each other and belief in each other's ability to embody effective communication, and (5) group process effectivity, where the knowledge on things that support and not support the group success (Johnson \& Johnson, 2003). Additionally, studies show cooperative learning affects conceptual understanding students on a science topic (Tsay \& Brady, 2010), problemsolving skills (Koçak, Bozan, \& Işik, 2009), and self-efficacy (Tanel \& Erol, 2007).

Cooperative learning also holds a critical role in the inquiry process since it guides students to cooperate like scientists in reviewing problems, arranging hypotheses, finding opportunities to solve issues and sharing their understanding to others (McConney, Wosnitza, \& Sturrock, 2016). However, one of the weaknesses of grouping students in cooperative terms is the number of group members that are too many, which will lead a person's effort and motivation to decrease or decrease due to the presence of other people in a group (Retnowati \& Aqilla, 2017).

Motivation comes from the internal and external environment of human beings that influencing their behavior and focuses toward a particular goal (Berger \& Hànze, 2009). It is assumed to accelerate self-efficacy (Britner \& Pajares, 2006), cognitive and metacognitive skills (Schunk \& Zimmerman, 2008), and a positive attitude toward science (Yang \& Chang, 2012). Student motivation is affected by four motivation domains, namely (1) attention which refers to curiosity; (2) relevance in learning that means the relation among students learning content and process with the learning purpose, learning style, experiences, student environment, as well as their future needs; (3) confidence, implying to someone's belief of having the competence to acquire success; and (4) satisfaction from completing the learning since students feel they have achieved their desirable target (Keller, 2010; Zheng, Ding, Lu, \& Branch, 2019). In this study students exercise how to form argumentation through some different activity patterns, such as collaborative and cooperative patterns. The aim of the study was to describe how the argumentation instruction using ADI with cooperative and collaborative discussion patterns affects students' motivation in learning a chemistry equilibrium topic.

\section{METHOD}

The research method used in this study was a case study. Case study is an empirical inquiry that investigates the case or cases by addressing the "how" or "why" questions concerning the phenomenon of interest. Quantitative and qualitative evidentiary sources should be combined in this type of study (Yin, 2002).

This study focused on students' motivation illustrated during the learning process within ten meetings. Two different teachers taught each group of the two groups. The teachers had professional experiences ranging from 3 to 8 years. In this study, the first author act both as the teacher and participant observer in one class (cooperative-ADI class) and as a participantobserver in the other class. The other teacher taught students in collaborative - ADI.

Before commencing the study, the researchers proposed a research permit application to the local education authorities that 
passed to the target school. Then, the researchers contacted the teachers in charge of the chemistry lesson for discussing the research process, organization of the lesson, and the class planned to be the subject of this study. The teacher who voluntarily helped to teach equilibrium in collaborative - ADI class was informed of the lesson plan constructed by the researchers and discussed how to implement it in the classroom. The observed students gave information about the research purposes, procedures, and interview process for some selected students before conducting the study. Besides, the researchers told them that their identities kept confidential.

The study involved a high school in Malang city with 64 grade $^{11}$ students $(23$ males and 31 females) and as participants who were learning chemical equilibrium in the age range 15 to 17 years old. The study conducted an initial observation to get information about cognitive skills in chemistry learning and the socio-economy background of participants. The school has a population that not very ethnically diverse (approximately 70\% Javanese and 30\% multiracial) and consists of children from a high socioeconomic background ( $65 \%$ of students receive a high amount of allowance per day). The formal language of instruction is Bahasa at schools and all students are able to speak and understand Bahasa. They have received chemistry lessons using the same curriculum at the same pace.

The next step was doing observation during the learning process, recording group discussion, interviewing and delivering the ARCS motivational questionnaire. During ten meetings (@90 minutes), students in cooperative - ADI and collaborative - ADI discussed five different topics. Those topics were dynamic equilibrium, equilibrium constant $(\mathrm{Kc})$ and gasphase equilibrium constant $(\mathrm{Kp})$, the relationship between $\mathrm{Kc}$ and Qc, the effect of change in concentration to equilibrium, the effect of change in volume and pressure factor to equilibrium, as well as the effect of a catalyst. After the process, teachers and researchers exchanged views and provided feedback to one another as they were analysis the recording.

The data were obtained from the learning process observation, group discussion recording, interview, and the answer from the ARCS motivational questionnaire. ARCS questionnaire was modified from Changeiwyo, Wambugu, and Wachanga's (2011) questionnaire, adapted with the students' context. The questionnaire consists of 20 items representing ARCS motivational indicators that consisted of attention, relevance, confidence, and satisfaction. Each of those indicators has five questions with Likert scale. The Likert scale asks the respondents to answer each item with extremely agree (SS), agree (S), doubtful (R), not agree (TS), and exceptionally not agree (STS). Each of the positive response was given score $\mathrm{SS}=5, \mathrm{~S}=4, \mathrm{R}=3, \mathrm{TS}=2$, and STS $=1$. Contrarily, each of the negative responses of SS, S, R, TS, and TS was given a score of $1,2,3,4$, and 5 . The questionnaire trialed to 63 students showed high reliability $(r=.762)$. The reliability from each aspect of the questionnaire is presented in Table 2. Additionally, the motivation questionnaire was distributed to students who had learned a chemical equilibrium topic. The results were analyzed to reveal the score range obtained by students. Besides, the results were also adjusted to the learning motivation criteria modified from Liang, Chen, Chen, Kaya, Adams, Macklin, \& Ebenezer (2008) as described in Table 1.

Table 1. Motivation Ccriteria Modified from Liang, Chen, Chen, Kaya, Adams, Macklin, \& Ebenezer (2008)

\begin{tabular}{ll}
\hline Motivation Criteria & Description \\
\hline Very motivated (VM) & all items score $>3$ \\
Motivated (T) & $60 \%-80 \%$ of the item score $>3$ \\
Less motivated (LM) & $60 \%-80 \%$ of the item score $<3$ \\
Unmotivated (U) & $\begin{array}{l}\text { all items score }<3 \\
\text { all items score }=3 \text { or random } \\
\text { Doubt (D) }\end{array}$ \\
& answers \\
\hline
\end{tabular}

The supporting data was collected from observation of the discussion process and group discussion recorded by students using audio or video recording tools. The researchers transcribed the results of the recording. The interview was conducted to six students, voluntarily, to get a more profound illustration of students' learning experience and motivation during the chemical equilibrium learning.

According to Yin (2002), data analysis in a case study consists of examining, categorizing, tabulating, combining both quantitative and qualitative evidence to address the purpose of the study. In this study the data were 
collected and analyzed by using Yin suggestion. Triangulation was done in order to obtain an accurate and accountable data by matching the data obtained through questionnaire, interviews, documentation, and observation.

\section{RESULTS AND DISCUSSION Results}

Results of students' motivation analysis from cooperative-ADI and collaborative-ADI (ADI) class on four ARCS learning motivation aspects are presented in Table 2.

These results indicate that the majority of students in the cooperative-ADI class feel motivated and highly motivated in learning chemical equilibrium. This data can be seen in the aspect of confidence, where cooperative-ADI class students look very confident. Whereas in the ADI class, students appeared more motivated in the aspect of relevance. It can be said that the cooperative pattern makes students feel more confident when learning, while the collaborative pattern makes it easier for students to find the relevance of learning chemistry. To support these findings, it is necessary to analyze interview data and transcript of student discussion activities in both classes.

The learning process applied to the Cooperative-ADI and the ADI class does not have much difference in terms of the learning steps, because both classes practice argumentation skills explicitly through the ADI learning steps. The treatment that is distinguished in this study is in the pattern of activity while practicing argumentation skills, using cooperative and collaborative patterns. An overview of learning steps in the Cooperative-ADI and CollaborativeADI can be seen in Table 3 .

Table 2. Percentage of Students' Motivation Criteria in Cooperative-ADI and ADI Class

\begin{tabular}{|c|c|c|c|c|c|c|}
\hline \multirow{2}{*}{ Aspect (Reliability) } & \multirow{2}{*}{ Class } & \multicolumn{5}{|c|}{ Criteria of Motivation (\%) } \\
\hline & & VM & M & $\mathbf{L M}$ & $\mathbf{U}$ & D \\
\hline Attention & Cooperative-ADI & 22 & 59 & 6 & 3 & 10 \\
\hline$(r=.942)$ & ADI & 13 & 53 & 9 & 6 & 19 \\
\hline Relevance & Cooperative-ADI & 44 & 34 & 13 & 3 & 6 \\
\hline$(r=.894)$ & ADI & 31 & 44 & 6 & 6 & 13 \\
\hline Confidence & Cooperative-ADI & 38 & 50 & 12 & 0 & 0 \\
\hline$(r=.838)$ & ADI & 31 & 38 & 25 & 3 & 3 \\
\hline Satisfaction & Cooperative-ADI & 34 & 47 & 16 & 3 & 0 \\
\hline$(r=.757)$ & $\mathrm{ADI}$ & 16 & 50 & 31 & 3 & 0 \\
\hline
\end{tabular}

Table 3. Cooperative and Collaborative Learning Procedures in ADI

\begin{tabular}{|c|c|c|}
\hline ADI Steps & Cooperative-ADI & Collaborative-ADI \\
\hline $\begin{array}{l}\text { Task } \\
\text { identification }\end{array}$ & $\begin{array}{l}\text { Students were divided into groups consisting of } 4 \\
\text { members formed by the teacher } \\
\text { Students divided tasks into groups according to the } \\
\text { guidelines on the worksheet. } \\
\text { The group leader ensured that each member had } \\
\text { understood their respective duties }\end{array}$ & $\begin{array}{l}\text { Students were free to choose other } \\
\text { students as discussion partners to study } \\
\text { the assignment given. }\end{array}$ \\
\hline Data collection & $\begin{array}{l}\text { Worked in groups by taking on their respective roles } \\
\text { during practicum }\end{array}$ & Carried out practicum in groups \\
\hline $\begin{array}{l}\text { Tentative } \\
\text { argumentation }\end{array}$ & $\begin{array}{l}\text { Each member reported the results of their respective } \\
\text { observations during the practicum process } \\
\text { Group members compiled their respective tentative } \\
\text { arguments and then discuss them in the group } \\
\text { Compiler group arguments as a result of an agreement }\end{array}$ & $\begin{array}{l}\text { Discussed to formulate arguments. } \\
\text { This stage could be done in groups or } \\
\text { individually. }\end{array}$ \\
\hline $\begin{array}{l}\text { Class } \\
\text { argumentations }\end{array}$ & $\begin{array}{l}\text { Each group presented the results of their discussion } \\
\text { and provided the opportunity for the other groups to } \\
\text { provide input or objections }\end{array}$ & $\begin{array}{l}\text { Students were allowed to exchange } \\
\text { ideas with students from other group } \\
\text { members according to their needs. } \\
\text { Each group presented the results of } \\
\text { their discussion }\end{array}$ \\
\hline $\begin{array}{l}\text { Reflective } \\
\text { discussion }\end{array}$ & $\begin{array}{l}\text { The group leader guided the group to review the group } \\
\text { work results and the inputs received during class } \\
\text { arguments } \\
\text { Put together a final report }\end{array}$ & Put together a final report \\
\hline Peer review & Reviewed the final report between groups & $\begin{array}{l}\text { Students were free to choose other } \\
\text { students to review the final discussion } \\
\text { report }\end{array}$ \\
\hline
\end{tabular}




\section{Discussion}

\section{Attention}

\section{Case 1: Cooperative-Argumentation}

The result of data analysis showed a higher percentage of students learning motivation affected by attention in cooperative-ADI class than the students in ADI class, as depicted in Figure 1.

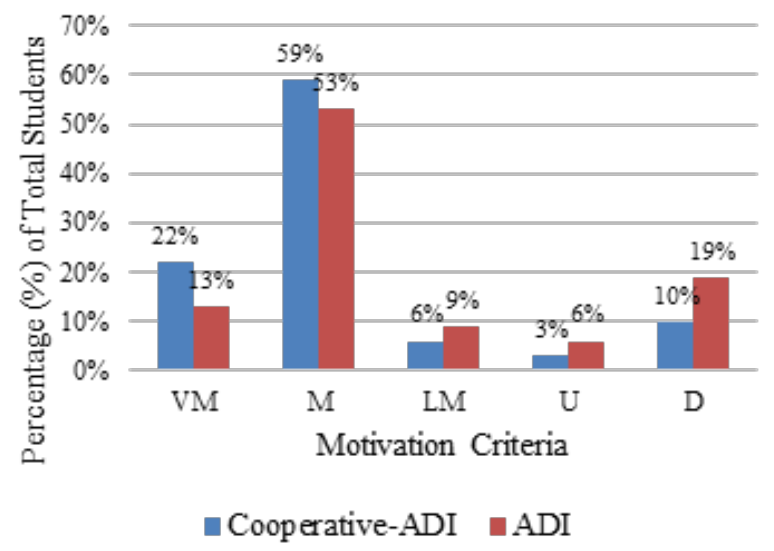

Figure 1. Cooperative-ADI and ADI Students' Learning Motivation in the Attention Aspect

The Figure 1 showed that cooperativeADI students paid considerable attention to the learning activities. That result was also approved by the observation results showing they were pleased when the teacher formed the groups. They also paid attention to the teacher's detailed explanation related to the argumentation procedure. Besides, they actively asked questions if they found issues in understanding argumentation's aspect, such as to warrant and rebuttal. They seemed to be excited during the discussion process, as illustrated in the transcribed group discussion below.

(Discussion of group 4 in Cooperative-ADI

class in the topic of equilibrium shift)

Putri : Now, I am going to deliver argumentation related to our discussed issue. I think sea pollution mainly happened because of industrial activities.

Qilla : I agree since industrial activities produce $\mathrm{CO}_{2}$ to the air.

Ani :I think the more suitable reason, according to the article, is the increasing amount of $\mathrm{CO}_{2}$, and they come to the water.
Putri : Right, the increasing concentration of $\mathrm{CO}_{2}$ shifted the equilibrium reaction to the left.

Ria : I think the equilibrium does not shift to the left but the right.

Qilla : From the explanation, I found in the book, the equilibrium shift on the opposite side of the accelerated concentration.

Ani : But we have to discuss up to the effect of the equilibrium, if it shifts to the product, then the acid amount increases.

Ria : Which part shows the acid?

Qilla : $\mathrm{HCO}_{3}^{-}$

The discussion about the equilibrium shift showed that students paid attention to each member's question and explanation, as well as completed each other answers to produce comprehensive group argumentation. They also actively raised questions when finding unclear information. From that analysis, there are cooperative aspects revealed, such as positive interdependence among students since they feel that they need each other to achieve the learning purpose; as well as individual responsibility. It seems that each member needs to master the fundamental concept from the discussed issues to contribute the right idea. The interaction that occurs in the cooperative discussion is mutual. According to constructivist theory, a mutual interaction will produce a positive learning environment, so that it can motivate students (Dagar \& Yadav, 2016).

\section{Case 2: Collaborative Argumentation}

Different results were obtained from interviews and observation of ADI class. Students in the ADI class were enthusiastic about learning when the teacher introduced the argumentation process and SSI topics about the processing of the fertilizer industry. Students exhibited a willingness to learn SSI topics by giving questions related to the part they had not comprehended to the teacher. However, they did not show enthusiasm during the group discussion; they tended to be not focused. The interview of four students from the ADI class supported the response to the questionnaire and observation.

(ADI students interview) 
Researcher:Do you like the overall learning process in your class?

Andi : I like argumentation.

Bintang : Not all of them.

Researcher : Why do you think so?

Andi : Ionly like classroom argumentation. The debate was exciting.

Bintang :I think the group discussion was not impressive.

Researcher: Why do you think so, S4?

Bintang : Because I don't think the group discussion help me to understand the material, it was only dominated by some students.

Researcher: Do you think you can concentrate on the whole of the process?

Bintang : I can, but I think I can better concentrate when I learn alone than in the group.

Andi : Me too.

Researcher:So, do you think in tentative argumentation you can concentrate better if you do it alone?

Andi : Yes.

Bintang : Yes.

The interview results of students from the ADI class seems to have better attention due to their involvement in the argumentation process. However, during the discussion process, they did not pay sufficient attention since the collaboration was not pleasurable. They think there was too much domination; thus, they were hardly concentrated. Chinn \& Clark (2013) mention that a different cognitive level in the collaboration group often triggers domination within the group, producing group results that tend to represent the particular student. This result is following Le, Janssen, \& Wubbles (2017) stated that in collaboration, group members rarely pay attention to each other ideas and tend to reject each other ideas without any justification.

\section{Relevance}

\section{Case 1: Cooperative Argumentation}

Relevance toward learning is the relation between the content and learning process towards learning goals and style, experiences, as well as the future needs of students (Keller, 2010). Figure 2 displays that the cooperative-
ADI class has a higher percentage in the aspect of relevance than that of the ADI class.

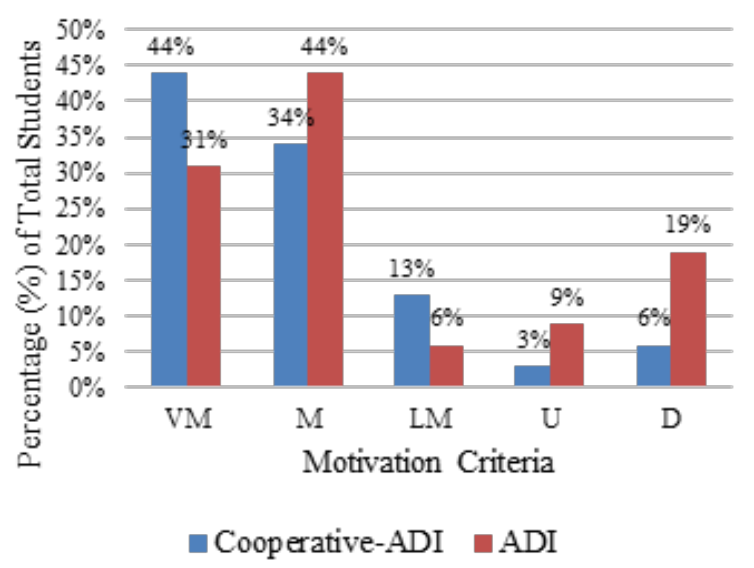

\section{Figure 2. Cooperative-ADI and ADI Students' Learning Motivation in the Relevance Aspect}

This study found that the majority of cooperative-ADI students achieved extremely motivated and motivated criteria in the relevance aspect. The results of an interview from two cooperative-ADI students supported the quantitative result.

Researcher:Did you know the purposes of studying chemical equilibrium?

Putri :Yes.

Ria :Yes.

Researcher : Can you mention one of them?

Putri : To help us understand and master the concepts associated with equilibrium changing factors in the industry and our surrounding.

Researcher: Are there other learning purposes that you feel have been obtained through this learning?

Ria :Yes. I think this process helps me to achieve my goal of being more active in class.

Putri : Other purposes like to get the best group discussion results.

Researcher : Did your group member help you achieve your goals?

Putri :Yes.

Ria :Yes.

Researcher : Then, in your opinion, are there any other benefits of learning chemical equilibrium? 
Ria : I think so because I become more aware of the chemical process inside my body since it is relevant to equilibrium reaction.

Putri : Also, to understand environment equilibrium, like the accelerated pollution because of vehicles that obstruct natural equilibrium.

Researcher: Where did you know those examples?

Putri : From the information gathered from the discussion and other sources, like the Internet.

Ria : Yes, I also knew it from my group members who accidentally read biology articles on the bloodstream system carrying oxygen involving equilibrium reaction.

Students recognized the learning purposes due to the existence of individual responsibility within cooperative groups that encouraged students to realize that their learning purpose was to complete the group tasks to attain collective successes (Laal, Gerenpaye, \& Daemi, 2012). The group discussion based on mutual support and trust also enables students to be more open in sharing their learning experiences. It eases them to comprehend and find the relation between materials, topics discussed, and their everyday life (Billet, 2009). By providing equal opportunity to argue for all group members, it will indirectly increase their literacy because they need to collect evidence and facts to strengthen an argument so that it will be easier for each group member to find the relevance of the material (Widyastuti, 2018).

\section{Case 2: Collaborative Argumentation}

Even if the ADI class also instructed argumentation within the learning process, yet the students demonstrated less motivation on the relevance aspect.

Researcher:Did you know the purposes of studying chemical equilibrium?

Andi : :Yes.

Bintang : What is learning purposes mean?
Researcher:The learning purposes related to what you planned to achieve from a learning process, such as the purpose of discussion or the purpose of the learning equilibrium concept.

Andi : The purpose was to complete the student worksheet.

Bintang : Yes, like to complete issues in the SSI article.

Researcher : Did your group member help you achieve learning purposes?

Andi : No. The discussion only focused on arguing with each other.

Bintang :During the tentative argument phase, I mostly worked alone, with less help.

Researcher:Is there another purpose achieved through this learning?

Andi :Ehmm. Yes, like I have mastered the right way to argue.

Bintang : No.

Researcher:Then, in your opinion, are there any benefits of learning chemical equilibrium? If there is any, please mention it.

Andi : Yes, we know the equilibrium was shifting factors like in the fertilizer industry.

Bintang :In my opinion, the benefit is giving society information about the industry danger to the sea ecosystem, such as in the Kalimantan sea.

Researcher : Where did you find those examples?

Bintang : From a teacher.

Andi : Student worksheet.

The students were not able to find the relation between the learning purpose and the process they experienced. Even if they were capable of explaining the chemical equilibrium learning benefit, but they were transfixed in the examples given by the teacher. Thus, there was no new information obtained through the collaborative discussion process that was supposed to help them reveal other relation between the materials and their surroundings. It seems that peer-feedback didn't appear. The lack of feedback received by students during the discussion, along with no group work evaluation, provoked the group members did 
not feel like they gained new information and knowledge, they tended to forget the discussion goal (Changeiywo, Wambugu, \& Wachanga (2011). Ineffective discussion induced some students cannot find the meaning and benefit of that discussion process (Janssen, Erkens, Kanselaar, \& Jaspers, 2007).

\section{Confident}

\section{Case 1: Cooperative Argumentation}

Confidence represents someone who believes in his competency to achieve success (Keller, 2010; Tunçel, 2015).

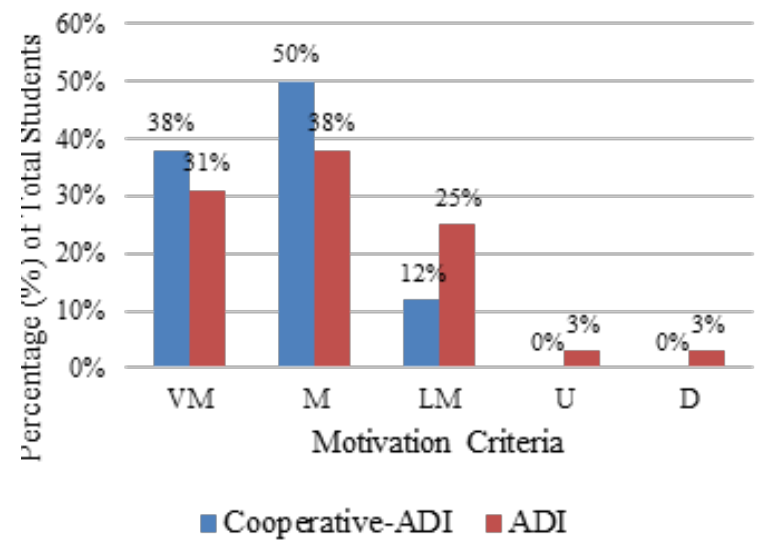

Figure 3. Cooperative-ADI and ADI Students' Learning Motivation in the Confident Aspect

Figure 3 displays the majority of cooperative-ADI students accomplished highly motivated (38\%) and motivated (50\%) criteria in the confidence aspect. This data revealed that the majority of students believe they are competent to succeed in learning equilibrium chemistry. The interviews with two cooperative classes confirmed the data.

Researcher: Are you surely understand about chemical equilibrium after learning argumentation in groups?

Putri : I am sure.

Ria :I am sure.

Researcher: Why?

Putri : Because I can do all of the parts in the test.

Ria : Me too. I felt that way because I saw my group members also become more understanding of the material after I explained it.
Researcher : In your opinion, does understanding chemical equilibrium materials make you more confident?

Ria :I think so. Not only mastering the materials but also the way to argue, so I become more confident in a discussion.

Putri :Yes, because if I master the materials, I can argue and become less nervous before the test.

Researcher: Do you feel more confident after learning in groups?

Ria :Yes, because the activities provide opportunities for me to express my ideas.

Putri : Emm...compared to the activity in the previous chapter, I think this group discussion makes me more confident.

Researcher:Then, are you also confident you can argue well if you don't learn in groups?

Putri : I don't think so, since if it is not in a group, then there is no one to assess if my argument is right or wrong.

Ria : Me too, since my friends often help me if I don't understand the material so that I can make a more robust backing argument.

Based on the interview, students seem to be eminently confident with their ability after they learn ways to argue in cooperative groups. This confidence is highly correlated with the mastery of concepts and learning materials received by students (Shallcross \& Spink, 2002). Mastery of concepts occurs if the teacher provided students the opportunity to interact with the contents; one of the ways is through argumentation (Songsil, Pongsophon, Boonsoong, \& Clarke, 2009). The students' activities also assisted the mastery of concepts during the learning process. Students discussed in the cooperative class with clear task division, which forces them to have individual responsibilities to boost the group's success. Gillies (2014) states that this process exhibits promotive interaction that provides opportunities for each group's member to solve their task in achieving collective goals. These opportunities provoked students to recognize their critical role affect the group's success that forces their confidence. 


\section{Case 2: Collaborative Argumentation}

Results of confidence aspect analysis in ADI class are slightly different from cooperativeADI. Even if the differences are not substantial, yet the observation results reveal that students in the ADI class argued in a less comfortable situation. In some observation phases, students chose to do the task individually. The interview with an ADI Andilso supports this observation result.

Researcher: Are you surely understand about chemical equilibrium materials after learning argumentation in groups?

Andi $\quad$ : I am not sure.

Bintang : Me too, there were some items that I could not answer during the test.

Researcher : Why aren't you sure?

Andi : Because I still have difficulties in understanding which chemical equilibrium concept that I should use in completing the argument items.

Researcher : In your opinion, does understanding chemical equilibrium materials make you more confident?

Andi : Yes.

Bintang : Yes.

Researcher: Do you feel more confident after you learn ways to argue in the group?

Andi : No.

Bintang : I feel more confident since I got a chance to express my opinion.

Researcher: Why S4 feel less confident in arguing in the group?

Bintang : Probably, it is because I choose the wrong group members, I often felt afraid to deliver my arguments since I knew that my friends had better arguments than theirs, so I just supported them.

Researcher : Then, do you feel confident without the group?

Bintang : Yes.

The students seem to feel less confident in delivering their arguments. Based on observation, the discussion in the ADI class was competitive, yet did not include all members. This atmosphere is due to a smarter student who tended to finish the difficult question, such as the problem analysis. In contrast, the lower cognitive students managed to work on more straightforward items, such as counting or writing the discussion results (Deveci, 2018). Consequently, students' confidences are low since they did not attain the chance to choose or arrange what they want in the group. Additionally, the discussion process was less enjoyable, constructing students' pressure and fear that affect their confidence (Chungang, Youmin, \& Shiyi, 2008).

\section{Satisfaction}

\section{Case 1: Cooperative Argumentation}

Satisfaction in learning covers students' happiness in achieving learning results and meaningful experiences (Keller, 2010).

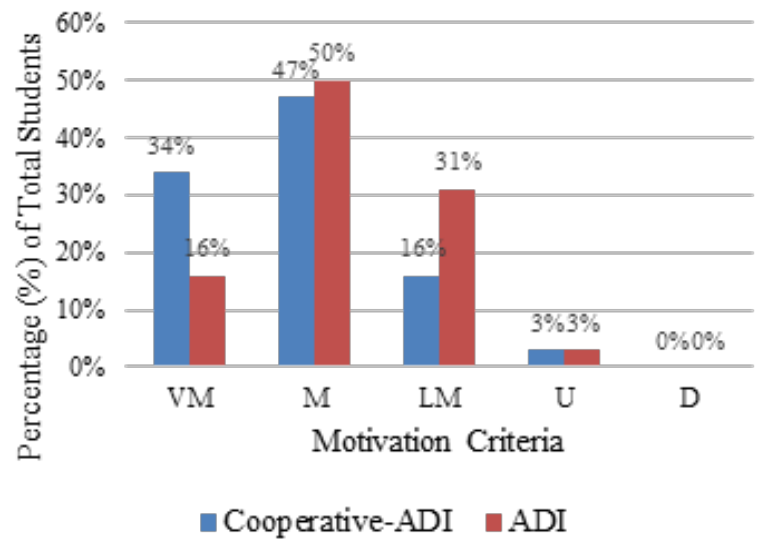

Figure 4. Cooperative-ADI and ADI Students' Learning Motivation in the Satisfaction Aspect

Figure 4 illustrates that students' learning motivation affected by satisfaction in cooperative-ADI class was higher than the ADI class. The result was also justified by the group discussion process in Group 2 of the cooperativeADI class.

Selli : Guys, I don't understand my part of the catalyst effect on the industry, whether it takes effect or not?

Dian : Catalyst also affects it, like in the reaction rate.

Putra : But, can it improve the amount of product in the industry?

Lani : Catalyst only accelerates the reaction rate, but it does not shift the equilibrium. 
Andi : Right, P.

Putra : I still do not understand, if it accelerates the reaction rate, why can't it improve the amount of the product?

Lani : Let's see the explanation on this page.

Dian : Oh, so the concepts of reaction rate and equilibrium are different?

Andi : From this explanation, they are different.

Putra : Then, I should choose 'not agree' in this catalyst addition. All right, I understand now.

Satisfaction in learning was profoundly affected by the cohesive group discussion process. During that discussion, students reciprocally helped to finish the tasks and avoid debates or domination that trigger uncomfortable talks. The favorable and synergetic situation during the cooperation allowed students to overcome difficulties they faced (Kangas, Siklander, Randolph, \& Ruokamo, 2017).

\section{Case 2: Collaborative Argumentation}

Additionally, the habit of arguing and express appreciation toward the results of cooperative work also increases students' satisfaction in their learning process (Liu, Lin, $\&$ Chang, 2010). In contrast, the satisfaction in the ADI class is lower than cooperative-ADI, as supported by the interview with two ADI students.

Researcher: Are you satisfied with the test results?

Andi : No, I'm not. My score is just right at the minimum completeness criteria.

Bintang : It is higher than the last test about reaction rate, but yet, it is still below my expectation.

Researcher: Are you pleased with that below expectation score?

Bintang : I'm satisfied since it is above the minimum completeness criteria, but still not pleased since it is below my target.

Researcher: In your opinion, what are the problems?

Andi : Probably, it is because I do not comprehend the material. I often forget and make mistakes.
Bintang : Yes. I feel the same.

Researcher: What about the discussion activities in the groups, are you delighted with them?

Bintang : I was not pleased. In my opinion, my group members were too passive. I mostly worked on my own.

Andi : Me too, my ideas were rarely utilized by the group. I also got minimum opportunities to respond to the questions during the class argumentation.

Researcher: Were there problems that appeared during the discussion, such as being uncomfortable or not suitable for each other?

Andi : Yes. If I gave a different opinion, I was seen as someone who hampered the group. Thus, I habituated of being in a group with my close friends.

The interview result displayed a domination tendency that generates conflicts in deciding the discussion results. This poor relationship within groups caused them to discover critical new information for conceptual mastery hardly. That was because they spent most of their time to debate in deciding the best opinion. Consequently, students were involved in an unexpected situation that contrasts with their plan to reach achievements. Thus, students did not like the learning process, affecting their dissatisfaction. In conclusion, ADI students with collaborative discussion feel that the discussion process was not sufficient, so they were not satisfied with the learning process.

\section{CONCLUSION}

This study showed that majority of students who learned to argue in a cooperative discussion group were more motivated in learning equilibrium chemistry than students in a collaborative discussion class. The results of the analysis on the four aspects of the ARCS showed that the criteria are highly motivated for the cooperative - ADI. Students felt confident due to the responsibilities were given to them in a cooperative group. They also easily discovered the relationship between the learning chemistry content and the surrounding environment or their 
need to attain achievements. On the contrary, students who tended to debate in defending their opinion cannot aid students who worked collaboratively in the ADI class to be more confident. Even if the discussion process in ADI class was practical, but it fails to help students create effective discussion results or to allow them to help each other. Thus, students presented dissatisfaction in learning. These findings have implications for teachers and future researchers. Teachers can train the student's argumentation with a suitable discussion process, accelerate the interaction among students, and discussed chemistry topics so that the learning atmosphere will increase their motivation to learn that led to higher learning achievement.

\section{ACKNOWLEDGMENT}

Our sincere thanks are addressed to the Chemistry Department of Universitas Negeri Malang. The school where this study was conducted and all stakeholders involved in this research.

\section{REFERENCES}

Bathgate, M., Crowell, A., Schunn, C., Cannady, M., \& Dorph, R. (2015). The learning benefits of being willing and able to engage in scientific argumentation. International Journal of Science Education, 37(10), 1590-1612. https://doi.org/10.1080/09500 693.2015.1045958.

Beatty, M. J., McCroskey, J. C., \& Heisel, A. D. (1998). Communication apprehension as temperamental expression: A communibiological paradigm. Communication Monographs, 65(3), 197-219. https://doi. org/10.1080/03637759809376448.

Berger, M., \& Hänze, M. (2009). Comparison of two small-group learning methods in 12thgrade physics classes focusing on intrinsic motivation and academic performance. International Journal of Science Education, 31(11), 1511-1527. https://doi. org/10.1080/09500690802116289.

Berland, R. K., \& Reiser, B. J. (2008). Making sense of argumentation and explanation. Instructional Science, 93(1), 26-55. https://doi.org/10.1002/sce.20286.
Billett, S, (2009). Realising the educational worth of integrating work experiences in higher education. Studies in Higher Education, 34(7), 827-843. https://doi. org/10.1080/03075070802706561.

Blumenfeld, P., Rogat, T., \& Krajcik, J. (2006). Motivation and cognitive engagement in learning environments. In R. Keith Sawyer (Ed.). The Cambridge handbook of the learning sciences. New York, NY: Cambridge University Press, pp 475-488. https://doi.org/10.1017/ CBO9780511816833.029.

Boekaerts, M., \& Cascallar, E. (2006). How far have we moved toward the integration of theory and practice in self-regulation? Educational Psychology Review, 18(3), 199-210. https://doi.org/10.1007/s10648006-9013-4.

Britner, S. L., \& Pajares, F. (2006). Sources of science self-efficacy beliefs of middle school students. Journal of Research in Science Teaching, 43(5), 485-499. https:// doi.org/10.1002/tea.20131.

Changeiywo, J. M., Wambugu, P., \& Wachanga, S. W. (2011). Investigations of students' motivation towards learning secondary school physics through mastery learning approach. International Journal of Science and Mathematics Education, 9, 1333-1350. https://doi.org/10.1007/ s10763-010-9262-z.

Chen, H. T., Wang, H. H., Lu, Y. Y., Lin, H. S., \& Hong, Z. R. (2016). Using a modified argument-driven inquiry to promote elementary school students' engagement in learning science and argumentation, International Journal of Science Education, 38(2), 170-191. https://doi.org /10.1080/09500693.2015.1134849.

Chinn, C. A., \& Clark, D. B. (2013). Learning through collaborative argumentation. In C. E. Hmelo-Silver, C. A. Chinn, C. K. K. Chan, \& A. M. O’Donnell (Eds.). International Handbook of Collaborative Learning. New York, NY: Taylor \& Francis, pp. 314-332. 
Chungang, L., Youmin, X., \& Shiyi, G. (2008). Impact of team conflict on team decision quality and satisfaction: An empirical research in China. Front Bussines Research China, 2(1), 1-14. https://doi. org/10.1007/S11782-008-0001-Z.

Condon, M., \& Ruth-Sahd, L. A. (2013). Responding to introverted and shy students: Best practice guidelines for educators and advisors. Open Journal of Nursing, 3(7), 503-515. https://doi. org/10.4236/ojn.2013.37069.

Dagar, V., \& Yadav, A. (2016). Constructivism: a paradigm for teaching and learning. Arts Social Science Journal, 7(4), 1-4. https:// doi.org/10.4172/2151-6200.1000200.

Day, S. P., \& Bryce, T. G. K. (2013). The benefits of cooperative learning to a socioscientific discussion in secondary school science, International Journal of Science Education, 35(9), 1533-1560. https://doi. org/10.1080/09500693.2011.642324.

Deveci, T. (2018). Student perceptions of collaborative writing in a project-based course. Universal Journal of Educational Research, 6(4), 721-732. https://doi. org/10.13189/ujer.2018.060415.

Ericson, P. M., \& Gardner, J. W. (1992). Two longitudinal studies of communication apprehension and its effects on college student's success. Communication Quarterly, 40(2), 127-137. https://doi. org/10.1080/01463379209369828.

Gillies, R. (2014). Cooperative learning: Developments in research. International Journal of Educational Psychology, 3(2), 125-140. https://doi.org/10.4471/ Ijep.2014.08.

Hampden-Thompson, G. \& Bennett, J. (2013). Science teaching and learning activities and students' engagement in science. International Journal of Science Education, 35(8), 1325-1343. https://doi. org/10.1080/09500693.2011.608093.

Janssen, J., Erkens, G., Kanselaar, G., \& Jaspers, J. (2007). Visualization of participation:
Does it contribute to successful computer-supported collaborative learning? Computers \& Education, 49(4), 1037-1065. https://doi.org/10.1016/j. compedu.2006.01.004.

Jocz, J. A., Zhai, J., \& Tan, A. L. (2014). Inquiry learning in the Singaporean context: Factors affecting student interest in school science. International Journal of Science Education, 36(15), 2596-2618. https:// doi.org/10.1080/09500693.2014.908327.

Johnson, D. W., Johnson, R. T. (2002). Cooperative learning and social interdependence theory. In R. S. Tindale, L. Heath, J. Edwards, E. J. Posavac, F. B. Briyant, Y. Suarez-Balcazar, E. Henderson-King, \& J. Myers. (Eds.). Theory and research on small groups. social psychological applications to social issues (vol 4). Boston, MA: Springer, pp. 9-33. https://doi.org/10.1007/0-30647144-2_2.

Kangas, M., Siklander, P., Randolph, J., \& Ruokamo, H. (2017). Teachers' engagement and students' satisfaction with a playful learning environment. Teaching and Teacher Education, 63, 274-284. https://doi.org/10.1016/j. tate.2016.12.018.

Kaplan, A. \& Flum, H. (2009). Motivation and identity: the relations of action and development in educational contexts - an introduction to the special issue. Educational Psychologist, 44(2), 73-77. https://doi. org/10.1080/00461520902832418.

Keller, J. M. (2010). Motivational design for learning and performance: The ARCS model approach. New York, NY: Springer. https://doi.org/10.1007/978-1-44191250-3.

Koçak, Z. F., Bozan, R, \& Işik, Ö. (2009). The importance of group work in mathematics. Procedia Social and Behavioral Sciences, 1(1), 2363-2365. https://doi.org/10.1016/j. sbspro.2009.01.414.

Laal, P. M., Gerenpaye, L., \& Daemi, M. (2013). 
Individual accountability in collaborative learning. Social and Behavioral Sciences, 9, 286-289. https://doi.org/10.1016/J. Sbspro.2013.09.191.

Le, H., Janssen, J., \& Wubbles, T. (2017). Collaborative learning practices: Teacher and student perceived obstacles to effective student collaboration. Cambridge Journal of Education, 48(1), 103-122. https://doi. org/10.1080/0305764X.2016.1259389.

Liang, L. L., Chen, S., Chen, X., Kaya, O. N., Adams, A. D., Macklin, M., \& Ebenezer, J. (2009). Assessing preservice elementary teachers' views on the nature of scientific knowledge: A dual-response instrument. Asia-Pacific Forum on Science Learning and Teaching, 9(1). https://www.eduhk. $\mathrm{hk} / \mathrm{apfsit} /$.

Liu, E. Z. F., Lin, C. H., \& Chang, C. S. (2010). Student satisfaction and self-efficacy in a cooperative robotics course. Social BehaviorandPersonality: AnInternational Journal, 38(8), 1135-1146. https://doi. org/10.2224/Sbp.2010.38.8.1135.

Lu, J., Chiu, M. M., \& Law, N. W. (2010). Collaborative argumentation and justifications: A statistical discourse analysis of online discussions. Computers in Human Behavior, 27(2), 946-955.https:// doi.org/10.1016/j.chb.2010.11.021.

McConney, A. W., Wosnitza, M., \& Sturrock, K. L. (2016). Inquiry and groups: Student interactions in cooperative inquiry-based science. International Journal of Science Education, 38(5), 842-860. https://doi.org /10.1080/09500693.2016.1169454.

Osborne, J., Simon, S., \& Collins, S. (2003). Attitudes toward science: A review of the literature and its implications. International Journal of Science Education, 25(9), 1049-1079. https://doi. org/10.1080/0950069032000032199.

Osborne, J. F., \& Patterson, A. (2011). Scientific argument and explanation: A necessary distinction? Science Education, 95(4), 627-638. https://doi.org/10.1002/ sce. 20438 .
Putri, P. A. W., Rahayu, S., \& Fajaroh, F. (2020). Efektivitas argument-driven inquiry untuk meningkatkan keterampilan berargumentasi ilmiah pada materi laju reaksi [The effectiveness of argumentdriven inquiry to improve scientific argumentation skills on reaction rate material]. Jurnal Pendidikan: Teori, Penelitian, dan Pengembangan, 5(1), 57-64. http://journal.um.ac.id/index.php/ jptpp/article/view/13132.

Retnowati, E., \& Aqilla, A. (2017). Efektivitas strategi pengelompokan berpasangan dalam pembelajaran matematika model core. [The effectiveness of the pairwise grouping strategy in learning mathematics in the core model]. Cakrawala Pendidikan, 36(1), 13-23. https://doi.org/10.21831/ cp.v35i1.12628.

Sampson, V., \& Clark, D. (2009). The impact of collaboration on the outcomes of scientific argumentation. Science Education, 93(3), 448-484. https://doi.org/10.1002/ sce. 20306 .

Sampson, V., \& Gleim, L. (2009). Argumentdriven inquiry to promote the understanding of important concepts $\&$ practices in biology. The American Biology Teacher, 71(8), 465-472. https:// doi.org/10.1662/005.071.0805.

Scager, K., Boonstra, J., Peeters, T., Vulperhorst, J., \& Wiegant, F. (2016). Collaborative learning in higher education: Evoking positive interdependence. Life Science Education, 15(4), 1-9. https://doi. org/10.1187/cbe.16-07-0219.

Schunk, D. H., \& Zimmerman, B. J. (2008). Motivation and self-regulated learning: Theory, research, and applications. New York, NY: Taylor \& Francis Group. https://doi.org/10.4324/9780203831076.

Shallcross, T., \& Spink, E. (2002). How primary trainee teachers perceive the development oftheirscientificknowledge:Linksbetween confidence, content, and competence? International Journal of Science Education, 24(12), 1293-1312. https:// doi.org/10.1080/09500690110110106. 
Simpkins, S. D., David-Kean, P. G., \& Eccles, J. S. (2005). Parents' socializing behavior and children's participation in math, science, and out-of-school computer activities. Applied Developmental Science, $9(1), \quad 14-30 . \quad \mathrm{https}: / /$ doi.org/10.1207/ s1532480xads0901 3 .

Songsil, W., Pongsophon, P., Boonsoong, B., \& Clarke, A. (2019). Developing scientific argumentation strategies using revised argument-driven inquiry (RADI) in science classrooms in Thailand. Asia Pacific Science Education, 5(7), 1-22. https://doi.org/10.1186/S41029-0190035-X.

Tanel, Z., \& Erol, M. (2007). Influence of cooperative learning techniques on student self-confidence and factors affecting learning physics. AIP Conference Proceedings, 899(1). https:// doi.org/10.1063/1.2733589.

Tsay, M., \& Brady, M. (2010). A case study of cooperative learning and communication pedagogy: Does working in teams make a difference? Journal of the Scholarship of Teaching and Learning, 10(2), 78-89. www.iupui.edu/ josotl.

Tunçel, H. (2015). The relationship between self-confidence and learning Turkish as a foreign language. Educational Research and Reviews, 10(18), 2575-2589. https:// doi.org/10.5897/ERR2015.2445.

Velayutham, S., \& Aldridge, J. M. (2013). Influence of psychosocial classroom environment on students' motivation and self-regulation in science learning: A structural equation modeling approach. Research in Science Education 43, 507527. https://doi.org/10.1007/s11165-0119273-y.

Waite, S., \& Davis, B. (2006). Developing undergraduate research skills in a faculty of education: Motivation through collaboration. Higher Education Research \& Development, 25(4), 403-419. https:// doi.org/10.1080/07294360600947426.

Widyastuti, S. (2018). Fostering critical thinking skills through argumentative writing. Cakrawala Pendidikan, 37(2), 182-189. https://doi.org/10.21831/cp.v37i2.20157.

Yang, C., \& Chang, Y. S. (2012). Assessing the effects of interactive blogging on Andittitudes towards peer interaction, learning motivation, and academic achievement. Journal of Computer Assisted Learning, 28(2), 126135. https://doi.org/10.1111/j.13652729.2011.00423.x.

Yin, R. K. (2002). Case study research: Design and methods. Thousand Oaks, CA: SAGE Publications.

Zheng, H., Ding, L., Lu, Z., \& Branch, R. M. (2020). The motivational effects of involving students in rubric development on animation instruction. Tech Trends: Linking Research and Practice to Improve Learning, 64(3), 137-149. https://doi. org/10.1007/s11528-019-00443-w. 